\title{
Atrioventricular thrombus in a 14-year-old patient: a case report
}

Yavuz Besogul ${ }^{1 *}$, Fatih Yılmaz ${ }^{1}$, Birsen Uçar ${ }^{2}$ Zubeyir Kılıç

\begin{abstract}
Right atrioventricular thrombus was diagnosed by echocardiography in a 14-year-old boy. Thrombus was reached through the right ventricle to the pulmonary artery and it was caused to tricuspit valve insufficiency. Surgical thrombectomy was performed and, he was treated with oral anticoagulation in postoperative period.
\end{abstract}

\section{Introduction}

Atrioventricular thrombus are relatively rare in the pediatric population, but when present they are a potential source of significant morbidity and mortality[1]. Echocardiography is a widely accepted method to detect intracardiac thrombosis. The echocardiographic appearance of intracardiac thrombus is a mainly apical mass with a defined border to cavum and myocardium [2-5] The treatment of intracardiac thrombus has been surgical thrombectomy or thrombolytic agents such as tissue plasminogen activator, streptokinase, or urokinase as well as anticoagulants such as heparin or warfarin.

\section{Case Report}

A 14-year-old male who had suffered from chill, nausea and vomiting for two weeks, was admitted to our hospital. Chest $\mathrm{x}$-ray film and routine biochemical screening including thyroid status were normal, and the ECG was a sinus rhythm. An infectious or autoimmunologic disease was not evident by immunologic and serologic tests. Cross-sectional echocardiography and transesophageal echocardiography demonstrated that there were masses which were $33 \times 26 \mathrm{~mm}$ in the right atrium and $26 \times 22 \mathrm{~mm}$ in the right ventricle (Figure 1, 2). There was no atrial septal defect. In the cardiac magnetic resonance (MR), these mass were thrombus and continued to pulmonary artery. It was decided to carry out surgical thrombectomy. Once, a median sternotomy and pericardiatomy, heparine (300 Units/kg) was administered intravenously before cannulation for cardiopulmonary bypass $(\mathrm{CPB})$ and additional dose was given to maintain

\footnotetext{
* Correspondence: ybesogul@gmail.com
'Department of Cardiovascular Surgery, No 67/22 Alpata Evleri, Eskisehir,

* Correspondence: ybesogul@gmail.com
'Department of Cardiovascular Surgery, No 67/22 Alpata Evleri, Eskisehir, Turkey
}

(c) 2010 Besogul et al; licensee BioMed Central Ltd. This is an Open Access article distributed under the terms of the Creative Commons

an activated clotting time of 450 or faster. Arterial cannulation was performed via the aortic root and venous return was supplied by direct superior vena caval cannulation. Cross clamping was placed to aorta when moderate hypothermia $\left(32^{\circ} \mathrm{C}\right)$ was occured and cardioplegia was infused into the aortic root for myocardial protection. When the right atrium was opened, the thrombus was appeared in the atrium through the ventricle via tricuspit valve. It was reached to pulmonary artery (Figure $3,4)$. Therefore, the pulmonary artery was clamped. When the atrioventricular thrombus was removed (Figure 5), the tricuspit was evaluated and found to be insufficiency. The atrium and ventricular wall was observed granular structure. After the valve was repaired, atrium was closed with a double layer of $3 / 0$ propylene sutures. The cross clamp and pulmonary clamp were removed and cardiac rhythm was spontaneously begun. Decannulation and neutralization of heparin were performed and, sternum was closed as usual. Postoperative echocardiography showed that there was no thrombus. The patient had an uneventful postoperative course with normal sinus rhythm and he was discharged from the hospital symtom-free with oral anticoagulation.

\section{Discussion}

Intracardiac thrombus, although relatively rare in the pediatric age group, have been increasing in recent years [6-8]. Pediatric intracardiac thrombus are most commonly diagnosed in patients with dilated cardiomyopathy and in patients status post Fontan operation. There is a male predominance[1]. The etiology in pediatric patients has yet to be clearly defined. Most pediatric studies have focused on underlying hematologic

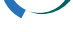




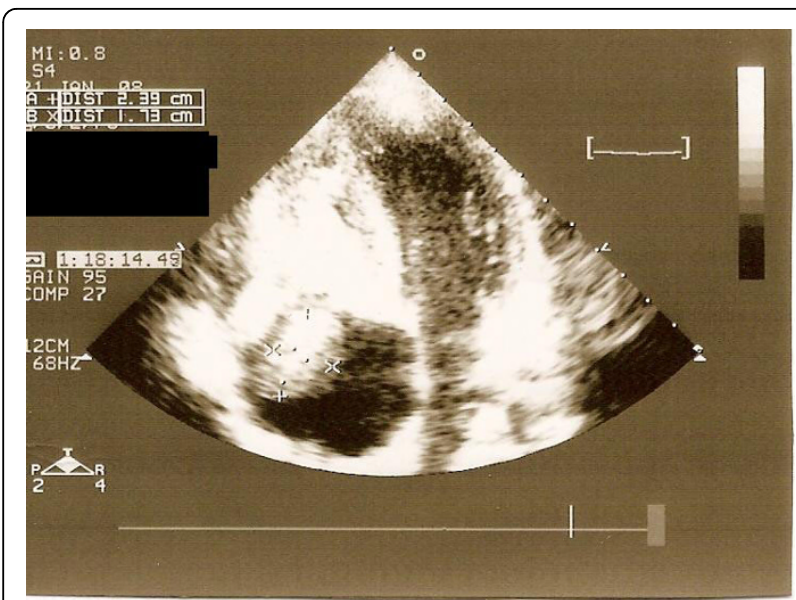

Figure 1 Echocardiographic view of the thrombi in the right atrium.

abnormalities, such as deficiencies in protein $\mathrm{C}$ and Factor $\mathrm{V}$, that could predispose one to have an intracardiac thrombus $[9,10]$. Right heart thrombus occurs in association with the presence of central venous catheters, vegetations due to endocarditis, polycytaemia, congenital heart defects, respiratory distress syndrome and persistent foetal circulation $[11,12]$. They have been shown to cause superior vena cava syndrome, occlusion of the tricuspit valve, and valvuler insufficiency with rapidly progressive heart failure. Additionally, main risk of the patients consists in unpredictable pulmonary embolization[13]. Ebato et al[14], reported that the patients have presented with symptoms of cerebral embolism and pulmonary embolism. The traditional therapy for intracardiac thrombus in pediatric patients has been surgical thrombectomy. In the largest pediatric study to date Ozkutlu et al[6], described the outcomes of 11 patients

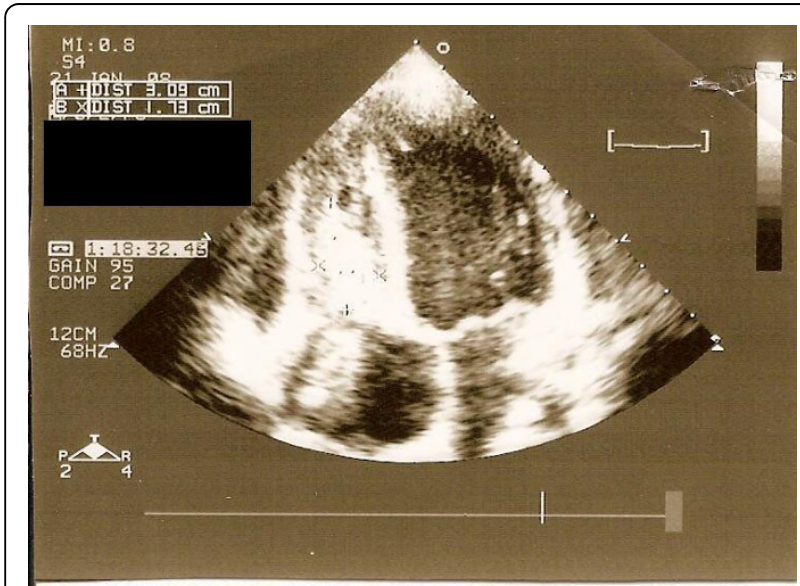

Figure 2 Echocardiographic appearance of thrombi in the right ventricle.

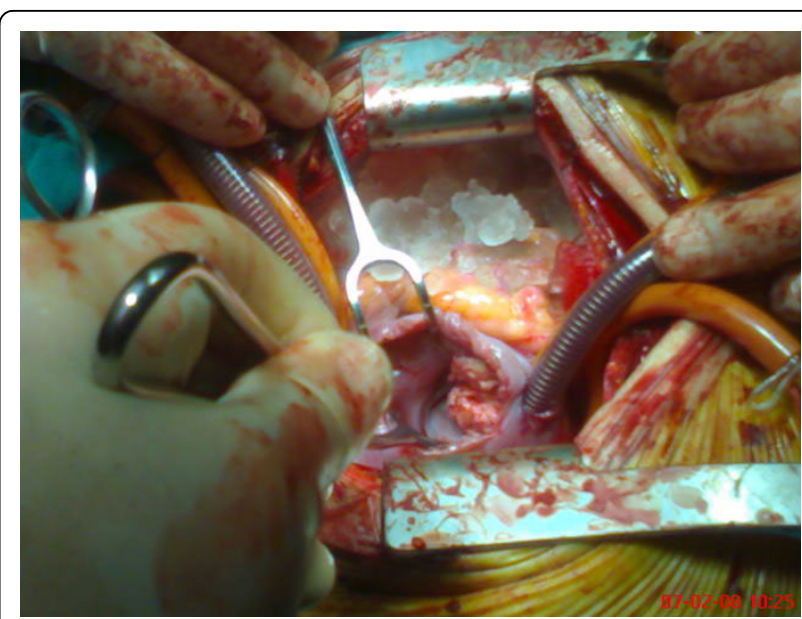

Figure 3 The appearance of thrombus from right atrium in the operation.

with intracardiac thrombus, 5 of whom underwent thrombectomy. Thrombolytics such as tissue plasminogen activator, streptokinase, or urokinase have been used routinely for the treatment of neonatal thrombus $[15,16]$. The optimal treatment modalities for children with intracardiac thrombus are not known. Information on management is limited to case reports and small case series. Moreover, spontaneous regression of intracardiac thrombus has been previously reported[13]. There was a tendency for smaller cardiac thrombus to resolve with medical therapy and for embolization to occur in patients with large thrombi[1]. We have performed surgical embolectomy because of the large thrombus in the atrium and ventricle.

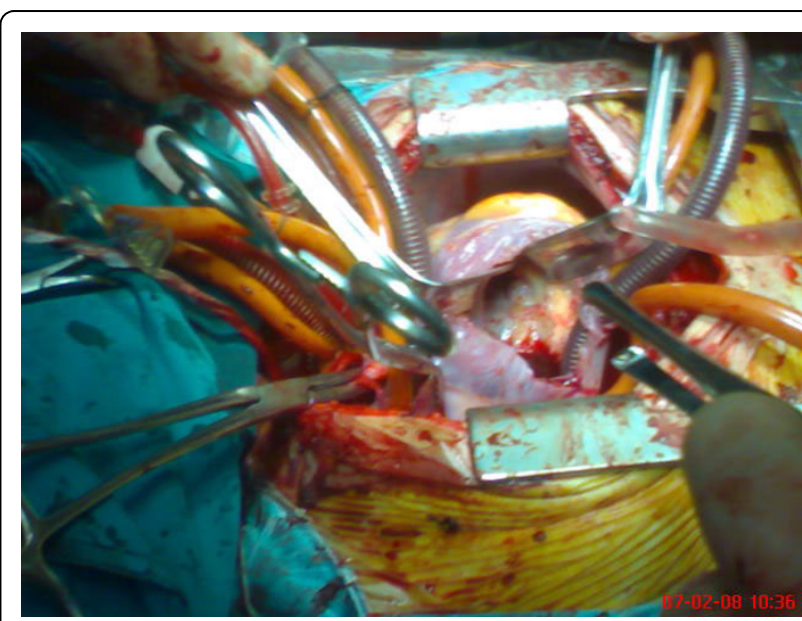

Figure 4 Operative photograph of the thrombus from the right atrium to the right ventricle. 


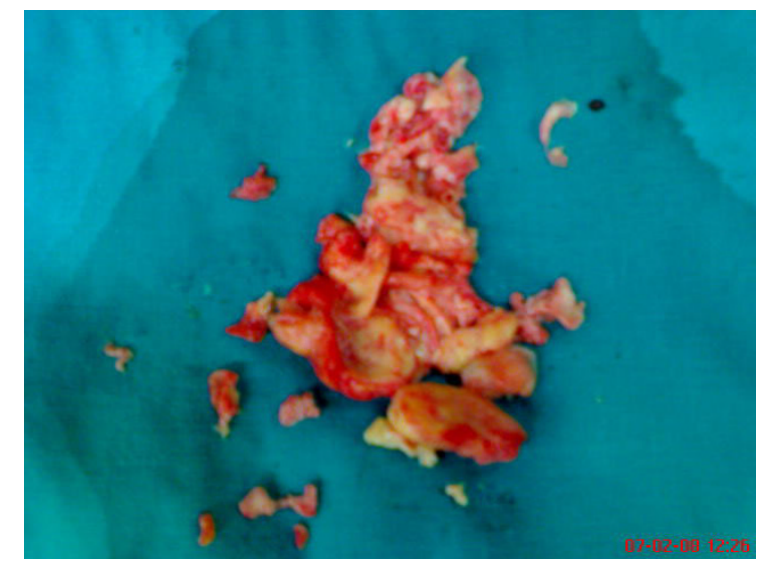

Figure 5 The appearance of thrombus after thrombectomy.

\section{Consent}

Written informed consent was obtained from the patient for publication of this case report and accompanying images. A copy of the written consent is available for review by the Editor-in-Chief of this journal.

\section{Author details}

${ }^{1}$ Department of Cardiovascular Surgery, No 67/22 Alpata Evleri, Eskisehir, Turkey. ${ }^{2}$ Department of Pediatric Cardiology, Osmangazi University Medical School and Research Hospital, Eskisehir, Turkey.

\section{Authors' contributions}

$\mathrm{YB}$; surgical treatment, study design, data analysis and writing FY; surgical photographs, and literature collection

$\mathrm{BU}$; diagnosis, echocardiography and preparation of the patient

ZK; diagnosis and echocardiography

All authors have read and approved the final manuscript.

\section{Competing interests}

The authors declare that they have no competing interests.

Received: 30 December 2008

Accepted: 2 February 2010 Published: 2 February 2010

\section{References}

1. John JB, Cron SG, Kung GC, Mott AR: Intracardiac thrombi in pediatric patients: presentation profiles and clinical outcomes. Pediatr Cardiol 2007, 28:213-220.

2. Krogmann ON, Kries RV, Rammos S, Kramer HH, Bourgeus M: Left ventricular thrombus in a 2-year-old boy with cardiomyopathy: lysis with recombinant tissue-type plasminogen activator. Eur J Pediatr 1991, 150:829-831.

3. Cujec B, Polasck P, Voll C, Shuaib A: Transesophageal echocardiography in the detection of potential cardiac source of embolism in stroke patients. Stroke 1991, 22:727-733.

4. Kapral MK, Silver FL: Preventive healt care,1999 update: echocardiography for detection of a cardiac source of embolus in patients with stroke. Can Med Assoc J 1999, 161:989-996.

5. Leung DY, Black IW, Cranney GB, Walsh WF, Grimm RA, Stewart WJ, Thomas JD: Selection of patients for transesophagealechocardiography after stroke systemic embolic events. Role of transthoracic echocardiography. Stroke 1995, 26:1820-1824.

6. Özkutlu S, Özbarlas S, Özme Ş, Saraçlar M, Göğüş S, Demircin M: Intracardiac thrombosis diagnosed by echocardiography in childhood. Predispozing and etioligical factors. Int J Cardiol 1993, 40:251-256.
7. Favara BE, Franciosi RA, Butterfield LJ: Disseminated intra. vascular and cardiac thrombosis of the neonate. Am J Dis Child 1974, 127:197-204.

8. Atalay S, İmamoğlu A, İkizler C, Uluoğlu Ö, Öcal B: Mitral valve and left ventriküler thrombi in an infants with acquired protein $C$ deficiency. Angiology 1995, 46:87-90

9. Atalay S, Akar N, Tutar HE, YIImaz E: Factor V 1691 G-A mutation in children with intracardiac thrombosis: prospective study. Acta Paediatr 2002, 91:168-171.

10. Gurgey A, Özyürek E, Gümrük F, Çelliker A, Özkutlu S, Özer S, Bilgiç A: Thrombosis in children with cardiac pathology: Frequency of factor $\mathrm{V}$ Leiden and prothrombin G20210A mutations. Pediatr Cardiol 2003, 24:244-248.

11. Ross $P$, Ehrenkranz R, Kleinman CS, Seashore JH: Thrombus associated with central venous catheters in infants and children. J Pediatr Surg 1989, 24:253-256.

12. Kádár $\mathrm{K}$, Hartyánszky I, Király L, Bendig L: Right heart thrombus in infants and children. Pediatr Cardiol 1991, 12(1):24-27.

13. Bendaly EA, Batra AS, Ebenroth ES, Hurwitz RA: Outcome of cardiac thrombi in infants. Pediatr Cardiol 2008, 29:95-101.

14. Ebato M, Kitai H, Kumakura H, Nakamura Y, Shimizu N, Takeyama Y: Thrombus on the tricuspit valve in a patient with primary antiphospholipid syndrome after implantation of an inferior vena cava filter. Circ J 2002, 66:425-427.

15. Aspesberro F, Beghetti M, Oberhänsli I, Ozsahin H, Humbert J, Rimensberger PC: Local low-dose urokinase treatment of acquired intracardiac thrombi in preterm infants. Eur J Pediatr 1999, 158(9):698-701.

16. Giuffre B, Compagnoni G, Farina C, Mosca F: Successful use of tissue plasminogen activator (t-PA) in catheter-related intracardiac thrombi of two premature infants. Acta Paediatr 1998, 87:695-698.

doi:10.1186/1757-1626-3-46

Cite this article as: Besogul et al:: Atrioventricular thrombus in a 14-

year-old patient: a case report. Cases Journal 2010 3:46.

\section{Submit your next manuscript to BioMed Central and take full advantage of:}

- Convenient online submission

- Thorough peer review

- No space constraints or color figure charges

- Immediate publication on acceptance

- Inclusion in PubMed, CAS, Scopus and Google Scholar

- Research which is freely available for redistribution
Biomed Central 